\title{
Carcinosarcoma of the Mediastinum: A Rare Cause of Vocal Cord Palsy and Progressive Dysphagia
}

\author{
Mediasten Karsinosarkomu: Vokal Kord Felci ve Progresif Disfajinin \\ Nadir Bir Nedeni
}

\author{
Nithya KANESAN $\odot$, Irfan MOHAMAD $\odot$, Norsyamira Aida MOHAMAD UMBAIK $\odot$, Norzaliana ZAWAWI $\odot$
}

Ethics Committee Approval: Not Applicable.

Conflict of Interest: The authors declare that they have no conflict of interest.

Funding: None.

Informed Consent: Informed consent was taken.
Cite as: Kanesan N, Mohamad I, Mohamad Umbaik NA, Zawavi N. Carcinosarcoma of the mediastinum: A rare cause of vocal cord palsy and progressive dysphagia. Medeniyet Med J. 2020;35:166-9.

\begin{abstract}
Carcinosarcoma is a rare type of malignant tumour that possess both the elements of carcinoma and sarcoma. They may occur in various locations such as the uterus, breast, thyroid, lung and gastrointestinal system. However, very few primary mediastinal carcinosarcomas have been reported. We are presenting a case of a 75-year-old male who presented with progressive dysphagia and hoarseness for 3 weeks. Contrast-enhanced computed tomography of the neck showed features of enlarged mediastinal necrotic nodes and the biopsy of this mass showed morphology and immunohistochemical profile that are consistent with carcinosarcoma. However, the patient succumbed to his illness soon after diagnosis.
\end{abstract}

Keywords: Mediastinal tumour, carcinosarcoma, dysphagia

öz

Karsinosarkom, hem karsinom hem de sarkom unsurlarına sahip nadir görülen bir malign tümördür. Rahim, meme, tiroid, akciğer ve gastrointestinal sistem gibi çeşitli yerlerde ortaya çıkabilirler. Bununla birlikte, bildirilen çok az birincil mediastinal karsinosarkom vardır. Bu çalışmada üç haftalık progresif disfaji ve ses kısıklığı yakınması ile başvuran 75 yaşında bir erkek hasta sunulmaktadır. Kontrastı bilgisayarlı tomografi boynu genişlemiş mediastinal nekrotik dügüumlerin özelliklerini göstermiştir ve bu kitlenin biyopsisinde karsinosarkom ile tutarlı morfoloji ve immünohistokimyasal profil göstermiştir. Bununla birlikte, hasta tanıdan hemen sonra hastalığa yenik düşmüştür.

Anahtar kelimeler: Mediastinal tümör, karsinosarkom, disfaji
Received: 26 February 2020

Accepted: 13 April 2020

Online First: 30 June 2020

Corresponding Author: I. Mohamad

ORCID: 0000-0001-8572-0514 Universiti Sains Malaysia Health

Campus, School of Medical Sciences, Department of Otorhinolaryngology-Head and Neck Surgery, Kelantan, Malaysia irfankb@usm.my

N. Kanesan

ORCID: 0000-0002-4189-3664

Universiti Sains Malaysia, Health Campus, School of Medical Sciences, Department of OtorhinolaryngologyHead and Neck Surgery, Kelantan, Malaysia

N.A. Mohamad Umbaik ORCID: 0000-0003-4556-7601 Universiti Sains Malaysia, Health Campus, School of Medical Sciences, Department of OtorhinolaryngologyHead \& Neck Surgery, Kelantan, Malaysia

N. Zawawi

ORCID: 0000-0003-3640-0383

Universiti Sains Malaysia, Health Campus, School of Dental Sciences, Kelantan, Malaysia 


\section{INTRODUCTION}

Mediastinal masses can be divided into anterior, middle or posterior compartment lesions based on lateral chest radiograms ${ }^{1}$. This differentiation can help clinicians to establish possible differential diagnosis. Carcinosarcomas are rare, biphasic tumours that have both malignant epithelial and mesenchymal elements such as cartilage, bone or skeletal muscle $e^{2,3}$. This uncommon type of malignancy can occur in any part of the body but mediastinal localization is even more rare ${ }^{4}$.

\section{CASE HISTORY}

A 75-year-old male chronic smoker with underlying hypertension and hyperlipidaemia presented with chief complaints of dysphagia and hoarseness for three weeks. The dysphagia was described as progressive with an insidious onset. He also noticed insidious onset of hoarseness for the same duration. His hoarseness did not resolve with voice rest. Besides, he also had globus sensation and frequent vomiting of undigested food. He had on and off fever with worsening lethargy and loss of weight of more than $10 \mathrm{~kg}$ in a month. He did not complain about any significant shortness

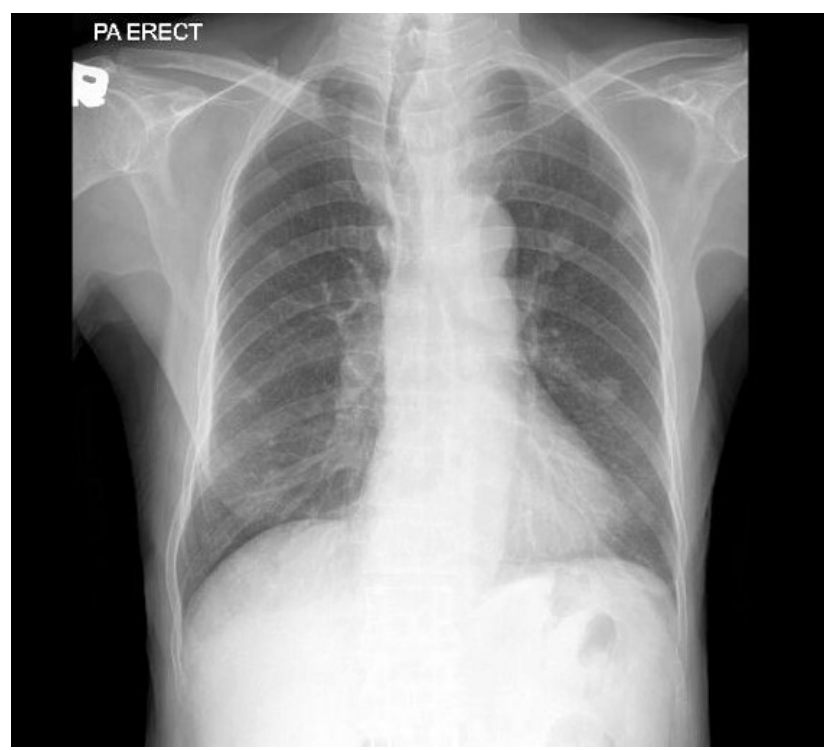

Figure 1. Chest radiograph showing left mediastinal mass causing deviated trachea. of breath or noisy breathing. He had no epigastric pain or regurgitation. There is no family history of malignancy as well.

Neck examination did not reveal any external scar. There was no palpable mass or lymph nodes. However, it was noted that the trachea deviated to the right. The oropharyngeal examination was unremarkable. Laryngoscopy revealed left vocal cord immobility in paramedian position. This was compensated by the contralateral vocal cord. However, there was no mass or lesion seen at the larynx and subsites of hypopharynx. Lung, and abdominal examination was unremarkable.
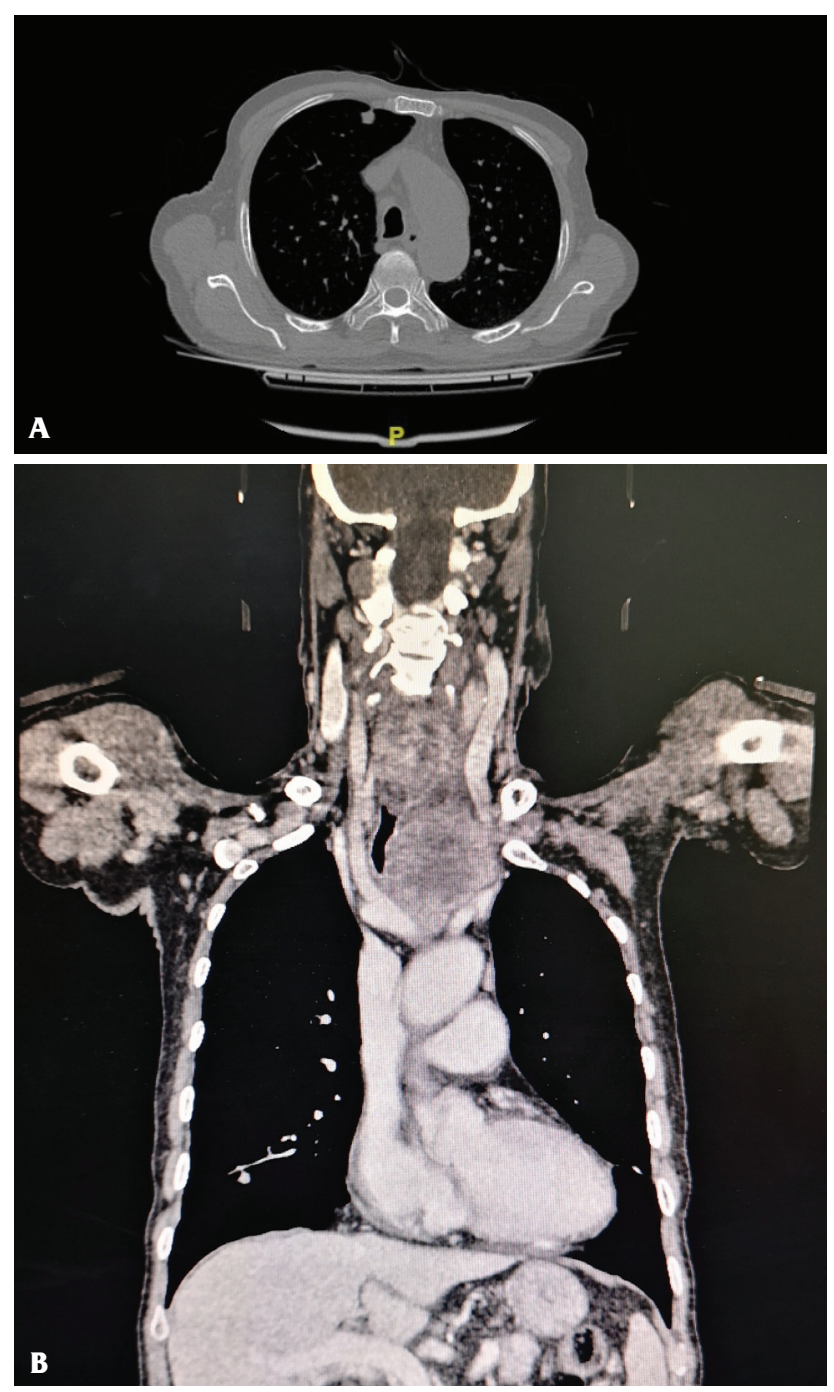

Figure 2. Axial and coronal view CECT thorax of the patient showing left mediastinal mass causing tracheal deviation. 
Chest radiograph showed mass over the left mediastinum pushing trachea to the right (Figure 1). Subsequently, contrast-enhanced computed tomography neck performd showed features of enlarged mediastinal necrotic nodes with likely metastatic multiple liver and lung lesions (Figure 2). Ultrasound-guided biopsy showed morphological and immunohistochemical profiles that were consistent with carcinosarcoma. Morphologically, the tumour was composed of sheets of epithelioid cells displaying moderate to markedly pleomorphic round-shaped nuclei, abundant eosinophilic to vacuolated cytoplasm, distinct cytoplasmic

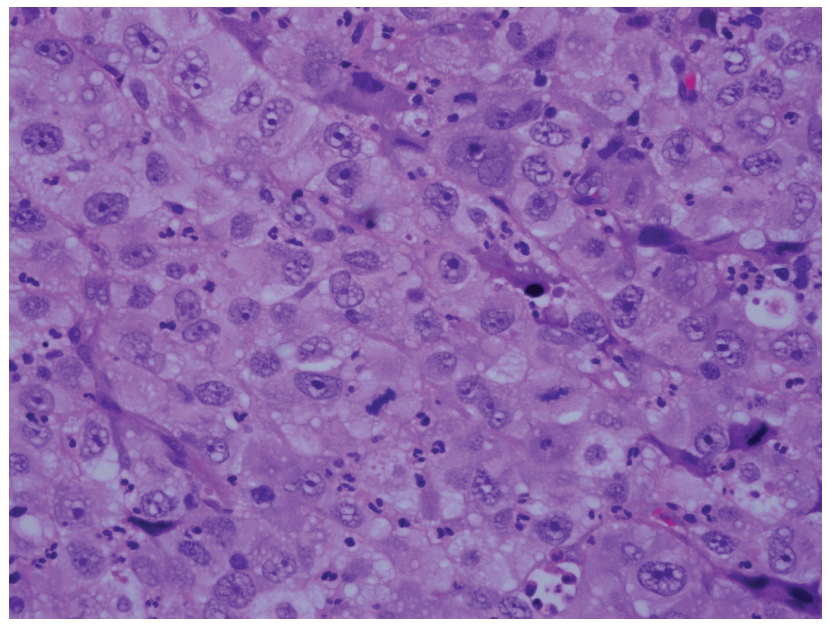

Figure 3. The tumour tissue shows neoplastic cells arranged in sheets. These cells are markedly pleomorphic with large, irregular vesicular nuclei and prominent large nucleoli. (H\&E stain, 400x magnification).

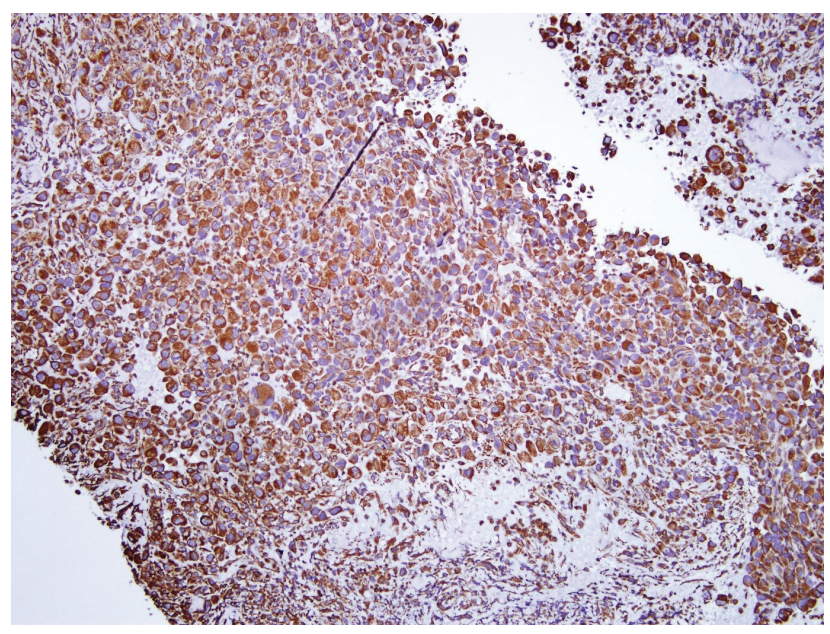

Figure 4. The tumour cells are diffusely positive for vimentin. (H\&E stain, 100x magnification). borders and some with prominent nucleoli. Some cells show plasmacytoid appearance. Sprinkles of mature lymphocytes were seen in some areas (Figure 3). Immunohistochemical status were diffuse and strongly positive for CKAE $1 \& 3$ and vimentin. CD 99 was also positive, however the latter is a nonspecific marker (Figures 4 and 5). The cells were negatively stained with other immunohistochemical markers including EMA, CD45, CD 30, ALK, S-100, HMB-45, myogenin and calretinin.

Patient then succumbed to his illness a week after the biopsy.

\section{DISCUSSION}

The mediastinum is bordered by the pleural cavity laterally, the thoracic inlet superiorly and the diaphragm inferiorly ${ }^{5}$. Mediastinum is further divided into anterior, middle and posterior compartments and occupies the medial aspect of the thorax cavity. Mediastinal tumours are comprised of various benign and malignant neoplasms that occupy the same anatomical location ${ }^{6}$. In 1999 Temes et al. mentioned that primary tumours and cysts of the mediastinum are rare, comprising approximately $3 \%$ of tumours within the chest. Among these, $25 \%$ to $49 \%$ of the lesions were malignant in ori$\operatorname{gin}^{7}$. Of the 219 patients with primary mediastinal malignancies, the most common type malignancy was lymphoproliferative in origin in $55 \%$, followed by germ cell tumours in $16 \%$ of the cases. Sarcoma accounted for $5 \%$ of all the primary mediastinal malignancies ${ }^{7}$. However, the reason for the rarity of carcinosarcomas was not explained.

Carcinosarcoma is a rare type of tumour characterized by both epithelial and other sarcomatous components. This can be a challenge during diagnosis and thus requires immunohistochemical examination ${ }^{4}$. The histology of these tumours can be controversial. The sarcomatous component may have arisen from a pre-existing carcinoma through mesenchymal metaplasia ${ }^{2}$. The presence 
of sarcomatous differentiation is associated with poorer prognosis ${ }^{2}$. This is also true in our patient where the patient succumbed to the illness soon after diagnosis even though he presented within the first month of onset of symptoms.

Common presenting symptoms of these patients include cough, chest pain, difficulty in breathing and fever. However, when there is tumour invasion or compression to surrounding structures, there could also be other symptoms such as respiratory compromise, dysphagia, Horner's syndrome or superior vena cava syndrome ${ }^{5}$. Our patient presented with these secondary symptoms of dysphagia and hoarseness.

A mediastinal mass can be seen preliminarily on a simple chest radiogram ${ }^{1}$. However, chest radiograph is usually not diagnostic except in rare cases of teratomas where teeth or bones can be seen within the mass or in the case of silicosis or sarcoidosis where there may be eggshell calcifications. For this reason, further investigation using a computed tomography (CT) scan is indicated to establish the diagnosis. This will help in evaluation of the anatomical location of the lesions, extent of the disease, tissue invasion and tissue density ${ }^{6}$.

Other imaging technique that can further aid in establishing a diagnosis is magnetic resonance imaging (MRI). This imaging technique is more superior to CT scan to identify nerve plexus and blood vessels, to distinguish tissue planes and invasions. This method of imaging is particularly useful if use of a contrast material is contraindicated and in assessing tissue, vascular or cardiac invasion by malignancies. However, MRI is used as a routine investigation, and mostly as a complementary investigation ${ }^{6}$.
Though imaging can vastly help in displaying morphology, density, extension, and vascularisation of these tumours, as well as adjacent structures and its relation to the tumour, surgical biopsy remains as an important tool for diagnosis ${ }^{8}$. Both benign and malignant anterior mediastinal masses would mostly require surgical resection. For this reason, in most cases, there is a limited role of invasive diagnostic methods that can potentially be risky. In these cases, surgical resection of the mass functions for diagnostic purposes and treatment ${ }^{6}$.

In conclusion, primary carcinosarcoma is an uncommon malignancy that has poor prognosis but patient would benefit from early diagnosis and treatment.

\section{REFERENCES}

1. Bayram AS, Ozdemir B, Aydiner F, Gullulu S. Carcinosarcoma as a primary mediastinal tumor. Interact Cardiovasc Thorac Surg. 2004;3:11-3. [CrossRef]

2. Kim KI, Flint JD, Müller NL. Pulmonary carcinosarcoma: radiologic and pathologic findings in three patients. AJR Am J Roentgenol. 1997;169:691-4. [CrossRef]

3. Bektaş SS, Bircan S, Bircan A, et al. Pulmonary carcinosarcoma: a case report. Turk Patoloji Derg. 2011;27:68-72. [CrossRef]

4. Kwas H, Zendah I, Khattab A, Ismail O, Hantous S, Ghédira $\mathrm{H}$. An exceptional localization of a rare tumor: primary sarcomatoid carcinoma of the mediastinum. Tunis Med. 2015;93:397-8.

5. Juanpere S, Cañete N, Ortuño P, Martínez S, Sanchez G, Bernado L. A diagnostic approach to the mediastinal masses. Insights Imaging. 2013;4:29-52. [CrossRef]

6. Yoneda KY, Louie S, Shelton DK. Mediastinal tumors. Curr Opin Pulm Med. 2001;7:226-33. [CrossRef]

7. Temes R, Chavez T, Mapel D, et al. Primary mediastinal malignancies: findings in 219 patients. West J Med. 1999; 170:161-6.

8. Cirino LM, Milanez de Campos JR, Fernandez A, et al. Diagnosis and treatment of mediastinal tumors by thoracoscopy. Chest. 2000;117:1787-92. [CrossRef] 